\title{
Reading Cardano with the Roman Inquisition: Astrology, Celestial Physics, and the Force of Heresy
}

Jonathan Regier, Ghent University

\begin{abstract}
In the first decades after the founding of the modern Roman Inquisition in 1542, Girolamo Cardano was the most prominent natural philosopher to face imprisonment and trial. A trove of Inquisitorial letters, decrees, and censurae have survived, offering a detailed picture of how, in the early years of its existence, the Roman Inquisition placed theological boundaries around astrology and natural philosophy. This essay covers the trial and identifies a critical point of contention: that Cardano allegedly naturalized heresy. It suggests that we view the Cardano affair as a reaction against a natural philosophy which threatened to constrain the Inquisition's right to judge enemies and execute that judgment. Finally, it discusses how, in light of the Inquisition's reading, we might consider Cardano's astrology as accommodating Christian doctrine.
\end{abstract}

Tn October 1570, the illustrious and controversial physician Girolamo Cardano was arrested on 1 suspicion of spreading heresy. He was sixty-nine years old, a professor of medicine in Bologna and one of the most widely read philosophers in Europe. His trial lasted several months, setting into motion an eventual prohibition by the Index of all his works except the explicitly medical. In the period of his trial, the modern Roman Inquisition was still relatively young, having been founded in 1542. Cardano was the most prominent of the first natural philosophers to be imprisoned and tried - at least until Giordano Bruno's ordeal in the last decade of the sixteenth century. Thanks to the valuable scholarship of Ugo Baldini and Leen Spruit, Cardano's Inquisition documents are readily available, edited and published alongside those of many sixteenth-century natural philosophers. ${ }^{.}$Cardano's file is by far the largest, combining bureaucratic letters and hundreds of pages of censurae (censor reports). This fact coincides with what we know of his status in

Jonathan Regier is a Fonds Wetenschappelijk Onderzoek research fellow at Ghent University. Recent publications have focused on the mathematization of nature in the early modern period. His current project explores the intersection of medicine, natural philosophy, and religion in sixteenth-century Europe. Department of Philosophy and Moral Sciences, Ghent University, Blandijnberg 2, 9000 Ghent, Belgium; jonathan.regier@ugent.be.

Acknowledgments. I would like to thank Steven Vanden Broecke and Pietro Daniel Omodeo for their invaluable comments and discussion. I would also like to thank Guido Giglioni and the two anonymous referees for their expert suggestions.

${ }^{1}$ Ugo Baldini and Leen Spruit, eds., Catholic Church and Modern Science: Documents from the Archives of the Roman Congregations of the Holy Office and the Index, Vol. 1: Sixteenth-Century Documents (Rome: Libreria Editrice Vaticana, 2009) (hereafter cited as Baldini and Spruit, eds., Catholic Church and Modern Science). Cardano's documents are ibid., Tome 2, pp. 1033-1472.

Isis, volume 110, number 4. (C) 2019 by The History of Science Society.

All rights reserved. 0021-1753/2019/0110-0001\$10.00. 
the Republic of Letters: his audience was vast, his books widely printed and referenced in both Catholic and Protestant regions. ${ }^{2}$ Actually, as Baldini and Spruit note, it is surprising how long the Roman Inquisition took to bring him to trial, given the intensity of their subsequent interest, as well as his popularity and originality. Several of his works had been prohibited in France, Spain, and Portugal since the 1550s and early 1560s. In Paris, his De subtilitate was prohibited the year after its publication. The reason for the delay in Italy was almost certainly Cardano's connections with elevated members of the Church hierarchy. ${ }^{3}$ However, once the Holy Office began to study his writings, he was all but trapped in the methodical fabrication of their judgment. Or, rather, as we will see in what follows, their judgment was already more or less determined from the very first letter of accusation. Subsequent reports would flesh it out and keep it fixed within a widening framework of guilt.

Apart from the contribution of Baldini and Spruit, Cardano's Inquisition documents, particularly the censurae, have remained largely unstudied. Yet these documents offer historians of science a wealth of insight into the relationship between theology and natural philosophy in the second half of the sixteenth century. Astrology was at the center of the Inquisition's case against Cardano, but he did not run into problems by casting or publishing horoscopes, although the practice of judicial astrology would be counted among his infractions. The work that initially brought him trouble was his De rerum varietate (1557), a long treatise of universal natural philosophy published some thirteen years before his trial. The key point of contention was over the effects of celestial influence. Cardano wrote that self-harming religious behavior was caused by an astrologically induced preponderance of black bile. In so doing, he characterized religious suffering, whether for the sake of heretical doctrine or of true faith, as an illness rather than a matter of free will. Right from the beginning, the Inquisition's reading focused on a unique complex characterized by themes of Providence and determinism: the matter of who acts on sublunar nature-God or celestial bodies - and the extent of human free will over and against natural causes. Even when censorial attention turned to the explicit practice of astrology, it remained fixated on underlying problems at the undefined boundary between the natural philosophical and the theological. This boundary was vague, more tacit than explicit, and a source of negotiation and conflict. For example, the Council of Trent had effectively banned judicial astrology but not natural astrology. Why? Because judicial astrology cut into the capacity of humans to choose freely between good and evil and of God righteously to judge them for their moral actions, whereas natural astrology concerned only the physical changes that the heavens wrought on the sublunar world through forces and qualities (natural astrology was tied to meteorology, medicine, and agriculture, among other disciplines). ${ }^{4}$ But all this left room for interpretation.

\footnotetext{
${ }^{2}$ The Inquisition archives support this view: "Moreover, the censors' assessments of his works and the numerous requests for licences to read his books reveal that Cardano had an immense audience, perhaps only exceeded by that of a few theological and literary authors." Ibid., p. 1033. Regarding Cardano's fame and the market for his books see Ian Maclean, "Cardano and His Publishers, 1534-1663," in Girolamo Cardano: Philosoph, Naturforscher, Arzt, ed. Eckhard Kessler (Wiesbaden: Harrassowitz, 1994), pp. 309-338.

${ }^{3}$ Baldini and Spruit, eds., Catholic Church and Modern Science, pp. 1033-1035.

4 "As a consequence, the difficulty of specifying with certainty those cases in which such influence was possible, and that of opposing deep-rooted beliefs and authoritative disciplinary traditions, meant that in the Christian tradition the view that utterly rejected astral influences, and therefore the validity of astrology, was secondary to one which rejected predictions about human actions and destiny ('judicial' astrology) but admitted-or did not exclude out of hand-predictions about organic and physical events ("natural' astrology)." Ugo Baldini, “The Roman Inquisition's Condemnation of Astrology: Antecedents, Reasons, and Consequences," in Church, Censorship, and Culture in Early Modern Italy, ed. Gigliola Fragnito, trans. Adrian Belton (Cambridge: Cambridge Univ. Press, 2001), pp. 79-110, on p. 82. For the Scholastic foundations of the distinction between judicial and natural astrology see H. Darrel Rutkin, Sapientia astrologica: Astrology, Magic, and Natural Knowledge, ca. 1250-1800, Vol. 1 (Dordrecht: Springer, 2019), pp. 173-234. It should also be said that a wholesale rejection of celestial influence would
} 
After all, if the stars affected the passions through an acceptable physical mechanism, then they could arguably sway an individual toward one course rather than another, or a kingdom toward sword rather than ploughshare, without ultimately infringing on free will. One of the advantages of having Cardano's Inquisition file is that we can closely examine how his censors determined what was in or out of bounds, particularly in the period between the Council of Trent and Sixtus V's bull Coeli et terrae creator Deus (1586), which flatly prohibited predictions based on "circumstances which 'inclined' one or more men to act in a certain way."

In what follows, I will first narrate Cardano's trial, before considering in some detail the censurae against his works, drawing several conclusions as to how the censors put boundaries around astrological theory. I will suggest that we characterize the Cardano affair only superficially as pushback against astrology; more deeply, it was a reaction against a natural philosophy that threatened to constrain the Church's right to judge its enemies and to execute that judgment. This point is an important one. Some twenty years after Cardano's trial, Giordano Bruno faced his decade of imprisonment and interrogation. Bruno's trial, as he himself understood it, was precisely a negotiation between philosophy and theology. Bruno demanded that his Inquisitors in Rome recognize his authority in matters of nature, and he believed that his philosophy was consistent with revelation - "on the condition," as Luigi Firpo puts it, "that dogmatic superstructures be severely trimmed down." As a final judgment was looming, and after he agreed to abjure on all major points, he could not hold himself back from offering philosophical qualifications and clarifications. The argument over who could speak authoritatively on nature would reach another inflection point in Galileo's trial, and much of Europe took note of the result. Even the proceedings against Giambattista Della Porta, although explicitly a matter of prohibited practice (necromancy), can be seen through the lens of a Church asserting itself in and against matters of natural philosophy. ${ }^{7}$ Cardano's censurae show how the Inquisition's involvement in natural philosophy was guided, at an early stage, by practical concerns about being able to assert its own legitimacy as an institution of judgment. As mentioned, one of the fundamental points of contention - arguably the fundamental point of contention in the initial stage of Inquisitorial suspicion-pertained to the character of heresy, which Cardano seemed to naturalize in the De rerum varietate.

Meanwhile, the trial allows us another point of entry into Cardano's philosophy. Although his censors were biased readers, they did seek to systematize his work and to expose what they saw as its dangerous coherence. Baldini has asked whether Cardano viewed himself as "definitely outside" the orthodoxy or as a frustrated member of the flock. I will suggest a related question: What, if anything, did the censors - judges of orthodoxy par excellence - overlook or underplay in their reading, which was motivated by a presumption of heresy? The Inquisition, I will argue, disregarded Cardano's attempts to characterize his astrology as a natural theology. In principle, he conceived of it as the science of that part of fate manifest in the heavens; and in practice, even

\footnotetext{
have severed the link between the terrestrial and the celestial established in Genesis, implying that God had created the heavens in vain.

${ }^{5}$ Baldini, "Roman Inquisition's Condemnation of Astrology," p. 91.

6 “. . . la verità certa e primaria, quella della propria filosofia, doveva parergli conciliabile con la verità rivelata, sia pure sfrondando duramente le sovrastrutture dogmatiche, ritenute in gran parte arbitrarie.” Luigi Firpo, Il processo di Giordano Bruno (Rome: Salerno, 1993), p. 109. Here and throughout this essay, all translations into English are my own unless otherwise indicated.

${ }^{7}$ See Neil Tarrant, "Giambattista Della Porta and the Roman Inquisition: Censorship and the Definition of Nature's Limits in Sixteenth-Century Italy," British Journal for the History of Science, 2013, 46:601-625. Della Porta's Inquisition proceedings lasted from 1574 to 1578 .
} 
when astrologers failed, he interpreted their failure as confirmation of humanity's fate to be judged by an ultimately inscrutable Father. ${ }^{8}$

\section{THE TRIAL}

At this point, it will be useful to discuss the trial in some detail. ${ }^{9}$ Cardano refers to his imprisonment in Bologna several times in his autobiography, the De vita propria liber, but he gives no hint about the background or the accusations. This is reasonable. The Inquisition was not feared only because it could exert judgment over a person's life and limb; it could also destroy reputations and livelihoods. Cardano, indeed, lost his position at the University of Bologna. But while he says nothing about the cause of his imprisonment, he does talk about the emotional turmoil that he experienced. Three days after his arrest, in the apartment that served as his prison, he shut himself in the bedroom to avoid the humiliation of exchanging niceties with his jailers. Once the door was fastened, it was struck by an unexplained blow that set the entire room shaking. At first, he took all this as a sign of his impending death. But the mysterious incident forced him to reflect on his situation. As he did, he realized that matters could be worse: younger men had suffered more grievously and lost more, whereas he was already at the end of his life. He resigned himself to this consolation. Eventually, he came to construe the sign as a message from his guardian spirit that he should maintain perspective. Cardano also recounts that on the day of his imprisonment he added "the image of a swallow singing under the eaves of a barn" to his family's coat of arms, alluding to the similarities between the swallow and his own nature: "it is harmless to mankind; it does not shun association with the lowly, and it is ever in contact with humankind without becoming familiar." ${ }^{10}$

Although it is not entirely clear why doctrinal authorities finally targeted Cardano in 1570, political conditions were ripe. The Counter Reformation was in full swing. The recent Council of Trent had on many contentious issues clearly demarcated the differences between Catholic and Protestant teachings. Meanwhile, the papacy had been asserting itself in a sustained effort, under several popes, to centralize power in the Church through institutional measures. ${ }^{11}$ The Inquisition served as the sharpest tool to advance this project of doctrinal alignment and centralization. This general situation helps to explain the Inquisition's status in Bologna during the years leading up to Cardano's trial. The city's Inquisitor, the Dominican Antonio Balducci, proved successful in remaining independent from local civic and ecclesiastical powers while working closely with Inquisitorial powers in Rome. We will see in a moment the nature of his

\footnotetext{
${ }^{8}$ Ugo Baldini, "L'edizione dei documenti relativi a Cardano negli Archivi del Sant'Ufficio e dell'Indice: Risultati e problemi," in Cardano e la tradizione dei saperi, ed. Marialuisa Baldi and Guido Canziani (Milan: FrancoAngeli, 2003), pp. 457-515, on p. 470. For Cardano's understanding of astrology see Girolamo Cardano, Commentariorum in Ptolemaeum de Astrorum iudiciis Libri IV, in Opera omnia, 10 vols., ed. Jean-Antoine Huguetan and Marc-Antoine Ravaud (Lyon, 1663) (hereafter cited as Opera omnia), Vol. 5, pp. 93-368, esp. p. 94.

${ }^{9}$ Michaela Valente has provided accounts of the trial in two fine articles. The account in the present study provides additional material on Cardano's experience, on the substance of the initial letter of accusation, and on local context. See Michaela Valente, "Facing the Roman Inquisition: Cardano and Della Porta," Bruniana e Campanelliana, 2017, 23:533-540; and Valente, "Correzioni d'autore' e censure dell'opera di Cardano," in Cardano e la tradizione dei saperi, ed. Baldi and Canziani, pp. 437-456. Cardano meditates on incarceration, its pains, and the potential that it offers for spiritual refinement in a fictional dialogue called Carcer. This dialogue, likely written during his incarceration in Bologna, was first published in 2014. In the dialogue Cardano visits a friend in prison, Lucilius, who represents a real-life friend imprisoned by the Inquisition in the early 1560s: Girolamo Cardano, Carcer, ed. Marialuisa Baldi, Guido Canziani, and Eugenio Di Rienzo (Florence: Olschki, 2014). ${ }^{10}$ Girolamo Cardano, The Book of My Life, trans. Jean Stoner (New York: New York Review of Books, 2002), pp. 183-184, 210, 122 (quotation).

${ }^{11}$ For an overview of this centralizing project see Robert Bireley, The Refashioning of Catholicism, 1450-1700: A Reassessment of the Counter Reformation (London: Macmillan, 1999), pp. 45-69.
} 
collaboration with Rome-his constant updates and, at key moments, requests for guidance. Among the trials spearheaded by Balducci were several against prominent figures in Bologna, including members of the nobility. The historian Andrea Del Col has noted the remarkable spike in Inquisitorial activity in Bologna between 1566 and 1569: some ninety imprisonments and trials, including twenty death sentences. ${ }^{12}$ It seems that Balducci's main ambition was to stamp out any trace of sympathy to reformed churches. Del Col describes the disastrous social and financial consequences that a Bolognese Inquisition trial during this period had for a suspected heretic and his family. ${ }^{13}$ Cardano's fears, in this light, were quite rational, as was his desire to leave Bologna and appeal in person to the Inquisitorial leadership in Rome. It is also important to note that Cardano was isolated in Bologna, a fact that becomes increasingly obvious in the trial documents (though even if he had been better protected, this by itself might not have helped him, given the independence of the Bolognese Inquisitor).

The beginning of Cardano's troubles can be traced to a letter written in May 1570 by the Inquisitor of Como, Gaspare Sacco, and sent in two copies: one to Scipione Rebiba, the Cardinal of Pisa and Dean of the Holy Office in Rome, and the other, now lost, to Balducci. ${ }^{14}$ The object of Sacco's ire was the De rerum varietate (On the Variety of Things). In this book, he wrote, "Cardano shows himself to be a bad believer, or rather a disbeliever, and he teaches errors, heresy and many superstitions, in my opinion." 15 The Inquisitor provided some examples of Cardano's failings. The very first concerned the power of celestial bodies: "And among other [errors], in book two, chapter thirteen, of the aforementioned treatise [De rerum varietate], where Cardano speaks of celestial influences, he so exaggerates them that he denies that God can act in inferior [sublunar] things. He denies the power of demons and calls the blessed martyrs crazy and driven by celestial influences into losing their property and life for the sake of uncertain things." ${ }^{16}$ Cardano, then, had put celestial causation over and above the authority of God and Church. Sacco continued with three other accusations worth citing in full:

And in book XV, chapter eighty, he calls the judges of the wicked and apostate impious, unjust, and rapacious wolves, and he mocks Saint Augustine. And in chapter 81, where he speaks of miracles ... he says that miracles are fictions and that the better part are invented by the testimony of priests whose nature is to lie. He then teaches chiromancy, hydromancy and other superstitions condemned by the sacred Council of Trent, along with many other errors, as you can see. ${ }^{17}$

\footnotetext{
${ }^{12}$ Eleven of those who received death sentences were convicted in absentia. For Balducci's activities in Bologna see Andrea Del Col, L'Inquisizione in Italia: Dal XII al XXI secolo (Milan: Mondadori, 2006), pp. 423-424 and, most importantly, 434-436.

13 "Gli effetti sociali prodotti a Bologna dalle detenzioni, processi, condanne e confische di beni furono a ogni buon conto notevoli: perdita della libertà, distacco dalla famiglia, deterioramento dei rapporti, difficoltà a continuare la professione o il lavoro per l'abitello che la sentenza imponeva di portare quotidianamente. Non provocarono solo un ostracismo morale, ma anche forti perdite economiche agli interessati e ai loro eredi." Ibid., p. 436. Balducci was effective in drawing money into Inquisitorial coffers through confiscation and fines. Some of this money was used for the construction of four Inquisitorial prisons in Bologna during his time as Inquisitor there. Ibid., pp. 423-424, 436.

${ }^{14}$ Baldini and Spruit, eds., Catholic Church and Modern Science, letter of 7 May 1570, pp. 1042-1043. Probably either Rebiba ordered Balducci to set up the trial or Balducci initiated it himself. It cannot be determined which of these scenarios is corrector whether there was another scenario entirely. See ibid., pp. 1068-1069 n 142.

15 “. . . nel q<ua>l libro intitolato de Varietate rerum esso Cardano se mostra mal credente anzi incredulo et insegna errori. heresie et molte supersticioni al guidicio mio." Ibid., p. 1042.

16 "Et tra li altri nel. 2. ${ }^{\circ}$ libro del sudetto libro al Cap. ${ }^{\circ} 13$ dove parla de influsi celesti tanto li ingrandisce che niega iddio operare in queste cose inferiori, niega la posanza di demonij et chiama li $s<a n>t i$ martiri pazzi et aggitati da celesti influsi a perder la robba et la Vita per cose incerte." Ibid.

17 "Et nel libro XV a capi 80 .carte .737. chiama li giudici de malefici et Apostate empij ingiusti et lupi rapacj et si beffa di S. Agustino. Et nel capo. 81. dove scrive de miracoli nel principio et a carte 749 nel fine dice li miracoli esser fittioni et la magior
} 
The Inquisition would weave a fabric of accusations against Cardano, such that the allegations would bolster and color one another. Sacco's letter is, in a sense, a miniature version of later censor reports, which is to say that Cardano's astrological positions were never attacked in a vacuum; they were always tainted by his alleged distrust of priests, sympathy for Lutherans, naturalist view of miracles, and embrace of myriad forms of illegitimate divination. Sacco's letter also shows that Cardano's alleged insults against the Church and its functionaries were a main point of contention.

Shortly after receiving Sacco's letter of accusation, the Holy Office began to investigate Cardano formally, ordering a report on the De rerum varietate that was completed over the summer. In Bologna, the logistics of Cardano's imprisonment, interrogation, and punishment were handled by Balducci, but Rome would make all the important decisions about his fate. Throughout, Balducci stayed in close contact with the Dean of the Holy Office, the aforementioned Cardinal Rebiba. Balducci's updates allow us to reconstruct a timeline of events. Cardano was arrested on 6 October 1570. The celebrated physician feared prison. He was, it seems, already aware of the imminent danger. Balducci boasts to the cardinal that he himself managed to lead Cardano to prison with such dexterity that the latter did not realize what was transpiring until it was too late. Some allowance was made for Cardano's age and infirmity - namely, a room with a fireplace and a personal servant to stay with him; this was accomplished at Cardano's own expense. ${ }^{18}$ By the end of October, the Holy Office demanded that Cardano be removed from his professorship at the university, a move authorized by the city's Legate and Senate several months later. Resentment at the university had been growing against him, and many of his colleagues publicly rejoiced when he was dismissed. Although he was a famous and prolific author, they complained that his teaching and medical practice had been sorely wanting. Even Pope Pius V celebrated his dismissal. ${ }^{19}$ Immediately upon finding himself held under lock and key, Cardano asked to be sent to Rome so that he could show his obedience and do whatever was necessary to placate those at the top of the hierarchy. He continued to make this request throughout the trial, as in a desperate, disjointed letter that he wrote directly to Cardinal Rebiba after over a month of imprisonment. This letter begins with a cry of despair, "Today is the forty-third day in prison. . . . I eat almost nothing because eating would drive me mad, not eating would drive me to death, which I consider the lesser evil." He notes that he cannot even speak to the help in the prison except for the time it takes to say an ave maria, this two or three times a week. ${ }^{20}$

By the end of December, Cardano's ordeal entered another phase. Balducci announced that he was ready to put together a local congregation to advise on the proceedings. Cardinal Rebiba ordered that Cardano be transferred to house arrest, likely in response to the latter's entreaty and to Balducci's requests for leniency. In return, Cardano had a student write in his name a letter of profuse gratitude to the cardinal. His love for the Church, he proclaimed, was so great that the trial could do nothing to diminish it. The dimensions of his love were like what the astrologers said about the size of the Earth: even the mountains, proportionally speaking, could take nothing

\footnotetext{
parte esser trovate per testimonio de sacerdoti quorum proprium est mentiri, insegna poi de chiromanzia. Hidromanzia et altre supersti<tio>ni dannate dal sacro concilio Tridentino et molti altri errori come si puo vedere.” Ibid., pp. 1042-1043.

${ }^{18}$ Ibid., letter of 7 Oct. 1570, p. 1069 (Cardano's fear of prison and Balducci's boast); and ibid., letter of 11 Oct. 1570 , p. 1070 (better room and live-in servant).

${ }^{19}$ Ibid., letter of 28 Oct. 1570, pp. 1073-1074 (demand for Cardano's removal from his professorship); and Valente, “'Correzioni d'autore' e censure dell'opera di Cardano" (cit. n. 9), pp. 443 (colleagues' complaints), 444 (pope's celebration).

20 "Hoggi di xliii giorni ch'io son in prigion in questi freddi di lxx anni mal sano e tra latre [perso] [il sonno] et io non manzo quasi niente [perche] manzando [veneria] a impazire non manzando a morire che reputo men male." Baldini and Spruit, eds., Catholic Church and Modern Science, letter of 18 Nov. 1570, p. 1075. Regarding his contact with the servants see ibid., p. 1076.
} 
away from its perfect roundness. ${ }^{21}$ The reader cannot help noting that astrology-even as technical astronomy - was probably not the best ground for pious analogies. In early February Balducci and his local congregation arrived at a recommendation for the Holy Office. Balducci made a point of telling the cardinal that he felt it would be unnecessary to frighten Cardano with threats of torture, since the suspicious propositions in his works were already clear. Balducci also worried about how Cardano would stand up to the ordeal. When the aged physician had first been taken to prison, he had collapsed, half dead, in the hands of the officers. "2. "What does Your Excellency think would happen," asked Balducci, "if he saw himself stripped and attached to the rope?"23

It was by now clear that Cardano would have to abjure. While Balducci awaited the final judgment from his superiors in Rome, he mulled over a number of procedural worries. For example, it would be nearly impossible to arrange a canonical purgation, a procedure in which the accused swore innocence before people who could guarantee his trustworthiness. He did not believe a single person who knew Cardano well enough to serve in that role could be found in Bolognaanother sign of Cardano's social isolation, despite his fame. There was also the question of the abjuration that would be required. For serious offenses, the Inquisition imposed one of two types: abjuration as a heretic (de formali) or abjuration as vehemently suspected of heresy (de vehementi). The former was reserved for grave cases, usually repeat offenders. The latter, it may be remembered, was required of Galileo decades later. Balducci was in favor of abjuration de vehementi, concerned that too harsh a punishment could push a desperate Cardano headlong into the camp of outright heretics. Given his literary gifts, there was a risk that he might become a truly formidable instrument of the Devil. The Holy Office in Rome responded on 14 February with their decree. Cardano would abjure de vehementi, as Balducci had recommended, and his books would be prohibited. ${ }^{24}$ Several weeks later, the Holy Office specified that his abjuration would be private, sparing Cardano additional humiliation. By mid-March, he was given permission to leave his house when necessary. The focus then shifted to the fate of his books. Balducci was expected to notify the other Italian Inquisitors of the prohibition of the De rerum varietate. Cardano wrote to Cardinal Rebiba again, protesting that while parts of the book merited correction, others had been interpreted in ways completely contrary to his intentions. He offered to write an apology and to expurgate infelicitous passages. Cardano relocated to Rome in early autumn, arriving in the city, as he says in his autobiography, "on the day of the celebrated victory against the Turks, October 7, 1571." ${ }^{25}$ There, in the few remaining years of his life, he would serve as personal physician to two popes and join the College of Physicians. The Holy Office and the newly formed Congregation of the Index continued to amass censurae on a spectrum of his books. In October 1572 the Index officially prohibited all his writings except the explicitly medical. ${ }^{26}$

\section{THE CENSURAE AND CARDANO'S NATURAL PHILOSOPHY}

As mentioned earlier, the focal point of the Bologna trial was one of Cardano's most widely read works, the De rerum varietate (1557), which he saw as a companion to his De subtilitate, such

\footnotetext{
${ }^{21}$ Ibid., letter of 20 Dec. 1570, p. 1078 (Balducci's announcement); ibid., letter of 22 Dec. 1570, p. 1079 (Rebiba's order); and ibid., letter of 23 Dec. 1570, p. 1080 (Cardano's response).

22 “. . . e cadde in terra, mezzo morte in mano de sbirri." Ibid., letter of 3 Feb. 1571, p. 1083.

23 "Hor pensi .V.S. Ill. ${ }^{\text {ma }}$ che sarebbe se si vedesse spogliato ligare alle fune?" Ibid.

${ }^{24}$ Ibid., letter of 10 Feb. 1571, pp. 1084 (regarding Cardano's isolation in Bologna), 1084-1085 (preference for abjuration de vehementi); and ibid., Decree of the Congregation of the Holy Office, 14 Feb. 1571, pp. 1085-1086.

${ }^{25}$ Ibid., letter of 21 Mar. 1571, p. 1089, including n. 199 (prohibition of the De rerum varietate); ibid., letter of 22 Mar. 1571 , p. 1090 (Cardano's argument for correction); and Cardano, Book of My Life (cit. n. 10), p. 17.

26 "Cardanj opera quae de Medicina non tractant reprobantur." Baldini and Spruit, eds., Catholic Church and Modern Science, Decree of the Congregation for the Index, 29 Oct. 1572, p. 1209.
} 
that the two formed a whole devoted to every aspect of nature. The 1560 edition of the De subtilitate refers to it many times, including a passage in which Cardano writes of a dream where, standing in paradise after his death, a copy of the De rerum varietate was shown to him. ${ }^{27}$ No doubt the Holy Office would have disagreed about the presence of this book among the eternally blessed. As we saw above, they arranged for a censura of the work almost immediately upon receiving the Inquisitor of Como's accusation. This report, written by an anonymous official, follows the two main lines of attack set out by the Inquisitor: that Cardano imputes to natural forces what should be imputed to God alone and that he casts suspicion on ecclesiastical authorities.

It would be an understatement to say that the censor approached the text with a critical eye. The De rerum varietate begins with a discussion of whether or not the universe was created; Cardano reserves his final word for another treatise, the De arcanis aeternitatis, which he had begun writing decades before but which would not be published during his lifetime. It is scandalous, says the censor, that Cardano would let doubts linger about so important a point raised at the very beginning of his treatise: "But in a Christian, and even worse one suspected of heresy, it is intolerable in these times, just as the Athenians would not endure that Socrates teach the Unity of God, nor Aristotle the eternity of the world. In their law, they had as heresy those things that corrupted the Athenian youth." 28 The reader might be surprised to find a censor for the Holy Office, in a text meant strictly for his colleagues, defending the Athenians for putting Socrates to death. It is even tempting to see here a kind of cultural relativism avant la lettre, which would be an exaggeration of what the censor probably meant: if the Athenians silenced their philosophers, how much more justified was the Holy Office in silencing the wayward thinkers in its own spheres of influence. The censor quickly establishes his line of attack: to search for threats to divine Providence. Nowhere is his attitude clearer than when he gets to Book 2 of the De rerum varietate, devoted to the celestial region. Here, he writes, Cardano subjects the "law of Christ" (i.e., Christianity) to celestial motion. ${ }^{29}$ The brunt of the criticism is reserved for Chapter 13, on celestial influence or "a certain occult force of the stars" ("vim quondam syderum occultam"). This was the chapter that the Inquisitor of Como had singled out as the first and perhaps foremost example of Cardano's heretical beliefs. Cardano, writes the censor, has all mortals ruled by this influence. These are indeed Cardano's own words as he opens the chapter: "Nobody should doubt that celestial influence exists: that is, an occult force by which all mortals are ruled." ${ }^{30}$ What then follows in the De rerum varietate is an extraordinary series of pages wherein Cardano attributes religious conflict and the proliferation of sects to the effects of this celestial influence. Who, Cardano asks, has not marveled that so many men voluntarily desert their children and wives, their lands and countries, and even subject themselves to torture, all for "so many varied opinions on religion?"31 These people support their suffering as if petrified (quasi lapidei). There is little doubt that Cardano views such religious behavior as extreme, specifically because it entails mortal danger for uncertain gain. It also does not occur in isolated incidents but tends to manifest in

\footnotetext{
${ }^{27}$ The censura prepared in response to the Inquisitor of Como's accusation was based on the 1558 edition, which I also use: Girolamo Cardano, De rerum varietate libri XVII (Avignon, 1558). See also Cardano, The "De Subtilitate" of Girolamo Cardano, 2 vols., trans. John M. Forrester (Tempe: Arizona Center for Medieval and Renaissance Studies, 2013); for the passage reporting the dream see Vol. 2, p. 941.

28 "Sed in homine christiano, et quod est peius suspecto de heresi, non est his temporibus tollerandum, sicut noluerunt ferre Athenienses, quod Socrates doceret Unitatem Dei, nec Aristoteles aeternitatem mundi, habebant enim ista pro heresi in lege sua quae Atheniensem iuventutem corumpebant." Baldini and Spruit, eds., Catholic Church and Modern Science, pp. 1045-1046. ${ }^{29}$ Ibid., p. 1047.

30 "Influxum syderum esse, nemo dubitare debet: eamque vim occultam, qua omnia mortalia reguntur." Cardano, De rerum varietate (cit. n. 27), p. 82.

${ }^{31}$ Ibid.
} 
clusters, which suggests a natural cause overriding the inclination toward self-preservation found in all living things. One of Cardano's signature methodological approaches as a natural philosopher was to look for commonality in otherwise disparate experiences, with an eye toward cycles and exceptions - after all, this was the goal of studying variety and subtlety. The same cycles behind spates of failed or successful childbirth, or sickness, or the appearance of prodigies and great men, were also behind the recrudescence of martyrs and sects. Celestial influence was the common cause:

I marvel at all these people, who, although they see such an order of things in the sky, such power and magnitude of the [celestial] bodies, and, in certain of the bodies like the Sun and Moon, such evident influence, they seek absurd, worthless and unknown causes, abandoning those that are right under their eyes and most manifest. But ignorance and sectarian love account for these and other miracles. So those who say that God is the cause of all this, does it not shame them, as if they said that a King was servant, sutler, soldier and scribe, under the pretext that he commanded them all? ? $^{32}$

Cardano clarifies for his readers that the cycles of nature and generation, among animals and plants, must be attributed to celestial influence and certainly not to demons, chance, or the nature of the elements. Demons have no such physical power in the world; if they did, they could destroy their human enemies and offer great help to their allies. If chance ruled, there would be no order, yet the heavens manifest perpetual order. Finally, the elements cannot account for any kind of generation: no element is hot by its nature, and no generation takes place without the heat of stars and light (Cardano does not consider fire an element but instead a result of celestial heat). What exactly is celestial influence, then? It is nothing other than "a certain measure of celestial heat in magnitude, force and time of action, that is, however, uncertain to us." Since we witness equivalent forces, like magnetism, and do not doubt them, why would we deny similar forces in the most noble and eternal body, the heavens? ${ }^{33}$ This kind of argument was common among promoters of celestial influence. Yet Cardano immediately returns to the quixotic issue of people who die for religious beliefs: when celestial influence explains why they expose themselves to death for the sake of religion ("ob religionis cultum"), why lay their deviance in the lap of God, given all the forms of worship that have attracted adherents willing to suffer for their beliefs?

Or is God the author of contrary beliefs at the same time? Does he enjoy things sometimes in one way, sometimes in another, like a capricious man? Moreover, will he care very much about how he is worshipped, like the gods of the gentiles? On the contrary, all these [rituals] were inventions of exceedingly greedy priests. What about the cause? What else but that black humor, which stupefies certain of them and drives others mad..$^{34}$

\footnotetext{
32 "Ego uerò satis demiror hos omnes, qui cum uideant tantum rerum ordinem in coelo, tantam potestatem ac magnitudinem corporum, \& in quibusdam, puta Sole ac Luna, tam euidentes effectus: relictis his quae sunt sub oculis ac tam manifestis, perabsurdas, inanes, \& incognitas causas, quaerere. Sed ignorantia \& amor sectarum haec \& alia magis mira facit. Igitur qui dicunt Deum, horum esse causam, nonne illos pudet, quasi si Regem dicant esse \& calonem \& lixam \& militem \& scribam, quod omnibus his imperet?" Ibid., pp. 83-84.

33 Ibid., p. 84.

34 “An Deus author est contrariorum simul? Aut modo his, modo illis, quasi inconstans uir delectabitur? Praeterea multum sollicitus erit, quibus modis colatur, uelut dij gentium? Imone illi [?], sed auarissimi sacerdotes, quorum omnia haec commenta fuere. Quid igitur causae est? Nonne potius humor ille ater, qui quosdam stupefacit, alios facit amentes?” Ibid., pp. 84-85.
} 
The question then comes down to how celestial influence acts on the body-and specifically to what influence has to do with the behavior of martyrs. In cases where pain is dulled, different factors can be at play. Cold, black humor can stupefy the mind and senses. Or a person can become insensible because of a "shocked mind" (mente perculsi), "as Hippocrates has taught." In yet other cases, an extreme focus of the mind can make us impervious to agony. Cardano remembers that, once in a state of intense study, he no longer felt the pain of gout raging in his foot. The key point in this discussion is that bodily humors respond to celestial motions, especially those of the Moon. These humors play on human life-our passions, our appreciation of pleasure and pain. The Moon, it should be mentioned, is the primary celestial body for Cardano's theory of critical days, owing to its influence over the flow of humors within vegetal and animal nature. ${ }^{35}$

What we find in this section of the De rerum varietate is something quite noteworthy: a direct link between martyrdom - or heresy - and celestial influence, written within a causal framework that is Galenic through and through (the heavens affect the humors in the body and can cause a buildup of black bile in the system). This is a variant on the "melancholy defense," for lack of a better term, that would also be used by Cardano with regard to witches. In fact, the two most well-known witchcraft skeptics of the century, Johann Weyer and Reginald Scot, would follow Cardano in ascribing witches' delusions to melancholy. ${ }^{36}$ But in the passages we have considered, Cardano is not accounting for demonic flights of imagination. He has extended the effects of melancholy to acts of religiously motivated self-harm. In doing so, he has made not only witchcraft, but also heresy, a medical matter. Cardano is not the first to have thought of overzealous religious behavior as mad or melancholic. There were a few precedents, of which the most notable was Ishâq Ibn Amrân, who had suggested that ascetics and the very pious were susceptible to melancholic delusions, through either fear or love of God, such that they seemed to suffer from an overheated love sickness. ${ }^{37}$ The early reformers, Luther and Zwingli, had associated Anabaptists with insanity and melancholy, as Angus Gowland has noted. In the seventeenth century the link between madness, melancholy, and religious enthusiasm would become commonplace. ${ }^{38}$ Yet Cardano is unique in the sixteenth century. From his natural philosophical or medical perspective, the question of right or wrong doctrine remains beside the point; the very fact of sacrificing one's life, family, or basic well-being for religious doctrine is lunacy. More to the point, it is natural lunacy: humoral passions were closely linked to celestial bodies in the astrology of the sixteenth century, allowing Cardano to associate the onset of religious zeal with celestial regularities.

It makes sense to add Cardano's views to the history of religious fanaticism, a concept whose modern definition Dominique Colas attributed to Philipp Melanchthon. Melanchthon used "fanatical" to describe Anabaptists, whom he saw as threats to the political structure supporting the Lutheran movement. But where Melanchthon understood Anabaptists as enacting a project against civil society and temporal power (a project to replace cities of man with a city of God),

\footnotetext{
${ }^{35}$ Ibid., p. 85 (gout). For Cardano's theory of critical days see Glen M. Cooper, "Approaches to the Critical Days in Late Medieval and Renaissance Thinkers," Early Science and Medicine, 2013, 18:536-565, esp. pp. 561-563.

${ }^{36}$ Regarding Johann Weyer see Stuart Clark, Thinking with Demons: The Idea of Witchcraft in Early Modern Europe (Oxford: Oxford Univ. Press, 1999), pp. 198-199. For Scot's views see Reginald Scot, The Discoverie of Witchcraft (London, 1584), pp. 52-59. For more on Cardano's view of witches see Germana Ernst, "Cardan et les sorcières," in La pensée scientifique de Cardan, ed. Jean-Yves Boriaud (Paris: Belles Lettres, 2012), pp. 3-22.

${ }^{37}$ Angus Gowland, "Burton's Anatomy and the Intellectual Traditions of Melancholy," Babel: Littératures Plurielles, 2012, 25:221-257, https://journals.openedition.org/babel/2078, paragraph 9 (the online version is not paginated). Ishâq's treatise on melancholy was available in Latin through Constantinus Africanus's translation.

${ }^{38}$ Angus Gowland, The Worlds of Renaissance Melancholy: Robert Burton in Context (Cambridge: Cambridge Univ. Press, 2006), p. 159; and Michael Heyd, "Be Sober and Reasonable": The Critique of Enthusiasm in the Seventeenth and Early Eighteenth Centuries (Leiden: Brill, 1995), pp. 44-64.
} 
the kind of fanaticism described by Cardano is not goal driven. It is a physical danger to the individual who manifests it. Because it is a form of madness, the correct response of both Church and state would presumably be to comfort or treat the individual rather than mete out punishment. Within the Church, there had long been comparisons between heresy and illness - as in Tertullian, who compares heresy to fever and stresses the weakness of heretics. ${ }^{39}$ However, her-

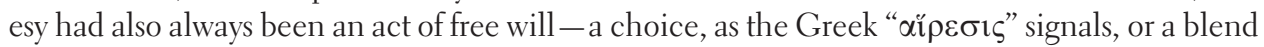
of choice and stubbornness, as Aquinas framed it. ${ }^{40}$ The Council of Trent had likewise affirmed, against Lutheran and Calvinist views, the capacity of human free will to accept or refuse God. In other words, the human will could voluntarily receive or decline spiritual grace and gifts. ${ }^{41}$ Cardano's medical view of religious variety seems blissfully unconcerned with the spiritual efficacy of human will. Nevertheless, it is worth noting that he does not argue for doctrinal tolerance here; he narrows the authority of the Church to persecute. He also implies that the best way to avoid the sway of sectarian opinions, and of their spokespersons, is to practice philosophy and understand nature. ${ }^{42}$

How did the original censor of the De rerum varietate read Cardano on celestial influence? To begin with, he took offense at Cardano's logic. Just because God inspired the blessed martyrs does not mean that heretics also followed divine inspiration; there is no charge of inconsistency from which God requires protection. The censor continues:

[Cardano] says that those enduring such suffering strive for uncertain things of no advantage, therefore the happiness of the other life is uncertain, and of no advantage. Furthermore, in the same chapter, he denies God to be the proper cause of all the blessed, and he diminishes God, and he mocks those who believe. He adds here that the diverse modes by which God is worshipped were inventions of covetous priests, due to the black humor that stupefied certain of them and drove others mad. ${ }^{43}$

Finally, the censor covers the factors by which celestial influence supposedly numbs people to suffering. "Here Cardano seems to secretly negate divine help and divine virtue in martyrs when they suffer." The censor's complaint is that Cardano makes no distinction between heretics and the Church's true martyrs. And this is indeed the case. The same censor will later note that

\footnotetext{
${ }^{39}$ Dominique Colas, "Fanatisme et société civile: 'L'ordre politique' chez Spinoza," Publications de l'École Française de Rome, 1991, 147:315-334, esp. pp. 322-324 (see also Colas, Le glaive et le fléau [Paris: Grasset, 1992]); and Tertullian, The Prescription against Heretics, Chs. 2 and 3, in The Ante-Nicene Fathers: Translations of the Writings of the Fathers Down to A.D. 325, ed. Alexander Roberts and James Donaldson, Vol. 3 (Buffalo, N.Y.: Christian Literature Publishing, 1885), pp. 243-244.

${ }^{40}$ Aquinas, Summa theologica, II.2, question 11. The Fathers of the English Dominican Province translation (New York: Benzinger, 1947) is available at https://dhspriory.org/thomas/summa/. It should be noted that Cardano identified irrational stubbornness as an effect of black bile. See Ernst, "Cardan et les sorcières" (cit. n. 36), pp. 11-12.

${ }^{41}$ See the numerous canons on justification. Canon V asserts the existence and capacity of free will. Canon VII, e.g., declares anathema anybody who believes in justification by "faith alone." The council affirms that a Christian must in some respect be "prepared and disposed" to grace by "the movement of his own will." Council of Trent, The Canons and Decrees of the Council of Trent, trans. Theodore Alois Buckley (London: George Routledge, 1851), p. 43.

42 "Quae cum ualidae fuerint, in his qui in philosophia exercitati non sunt, opiniones firmissimas \& absonas gignunt: quae postmodum per pessimos quosdam \& auarissimos uiros, in unum rediguntur atque formantur." Cardano, De rerum varietate (cit. n. 27), p. 85. On Cardano and the complex of techniques and disciplines involved in the management of the passions see Guido Giglioni, "Girolamo Cardano on the Passions and Their Treatment," Bruniana e Campanelliana, 2006, 12:25-40.

43 "Inquit, quod talia ferentes de re incerta contendunt, ac nullius commodi, ergo felicitas alterius vitae incerta est, et commodi nullius. Amplius in eodem cap. ${ }^{\circ}$ negat Deum benedictum cunctorum esse causam propriam, vilesceret enim Deus, eosque deridet qui ita credunt. Addit in eodem loco quod modi diversi quibus colitur Deus sacerdotum avarissimorum commenta fuere, et quod causa istorum est ater humor, qui quosdam stupefacit, alios facit amentes." Baldini and Spruit, eds., Catholic Church and Modern Science, p. 1048.
} 
Cardano largely denies the power of witches. That is also true, as just discussed. For Cardano, witchcraft reduces to a partly medical, partly social phenomenon. People believe themselves to be witches because of delusions caused by any number of physical issues: poor diet, black humor, astrological conditions, air, dread, and the retention of menstrual blood. Like other witchcraft skeptics of the period, Cardano saw the link between poverty, sickness, and the melancholy or madness that makes somebody a target for witch hunters, men whom he describes in the De rerum varietate as "ravenous wolves" that had lately given up chasing poor old women for a much more profitable prey: Lutherans. A printed note in the margin names these wolves as "Dominicans," playing on the pun domini canes. Years before his trial, Cardano had written in his De libris propriis that this short passage, so offensive to Dominicans, had been interpolated by an unnamed enemy and that his printer in Basel, Henricus Petrus, had not lifted a finger to help expunge it. ${ }^{44}$ The story is impossible to confirm and effectively irrelevant, since the passage was in the spirit of Cardano's earlier accusations against "greedy priests" who perverted the faith with fake rituals and superstitions, all for their own personal enrichment. Not only did such a statement cast serious doubt on his piety; it was also a popular Protestant talking point. Hence, in the first censura of the De rerum varietate we find astrological determinism fixed within an integrated network of accusations. One of the censor's most pronounced worries was that Cardano's view of nature, from the celestial reaches to the human body, nullified the Church's prerogative to judge its enemies: not only did the Church lose its justification to punish heresy, but the motives of its agents were seriously impugned. As a later censor would write, martyrdom is "a preeminent act of charity, to which a man cannot ascend by his own forces but requires special concurrence and divine help"; the death of heretics, on the other hand, is "an act of stubbornness."

After Cardano's trial and the decisive condemnation of his nonmedical output, the Holy Office and Index continued to produce censurae of his published writings, with an eye to later expurgation. Since the focus of this essay is the period of the trial itself, along with its initial triggers, I will not discuss these varied and detailed documents. I would like only to consider one consequential report, written up in Rome in 1572 or 1573, and the official list of heterodox propositions assembled from this report and given to Cardano for his response. ${ }^{46}$ The report is structured thematically, covering a number of topics on which Cardano expressed suspicious opinions in his writings. On the matter of astrology and influxus, it hews closely to earlier censurae, arguing that Cardano ascribed too much influence over human history to the heavens, both at the scale of the rise and fall of civilizations and religions and at the scale of the individual. It bears mention that in the long history of astrology, the rise and fall of civilizations and religions were frequently understood to depend in part on celestial conditions; in Latin Europe, the main source of this view was Albumasar, whose teachings had been Christianized by significant figures like Roger Bacon and Pierre d'Ailly. "So," writes the censor, "[Cardano] seems to make celestial bodies

\footnotetext{
${ }^{44}$ Ibid., pp. 1048-1049; Cardano, De rerum varietate (cit. n. 27), p. 737; and Girolamo Cardano, Libellus de libris propriis, in Opera omnia, Vol. 1, p. 112. See also Maclean, "Cardano and His Publishers" (cit. n. 2), p. 322.

${ }^{45}$ Baldini and Spruit, eds., Catholic Church and Modern Science, p. 1154. This censor was Alfonso Chacón, a noted humanist who would later occupy a prominent position in the Congregation of the Index. Chacón believed that the De rerum varietate was valuable and recommended that it be expurgated rather than prohibited. See Valente, "Facing the Roman Inquisition" (cit. n. 9), p. 537.

${ }^{46}$ Baldini and Spruit list the works from which the heterodox propositions were drawn: De consolatione, De rerum varietate, De supplemento almanach, De sapientia, De exemplis geniturarum, De mutatione aeris, Encomium astrologiae, De restitutione temporum et motuum coelestium, and De libris propriis. Baldini and Spruit, eds., Catholic Church and Modern Science, p. 1297 n 740

${ }^{47}$ See J. D. North, "Astrology and the Fortunes of Churches," Centaurus, 1980, 24:181-211. See also Laura Ackerman Smoller, History, Prophecy, and the Stars: The Christian Astrology of Pierre d'Ailly, 1350-1420 (Princeton, N.J.: Princeton Univ. Press, 1994), pp. 61-84.
} 
superior to God." Or: "He makes Christianity subject to celestial motion and stars." Or again: "Cardano here, on account of influxus, steals Providence from God." On the basis of this report, the Holy Office compiled an official list of 122 heterodox propositions given to Cardano for response. Astrology and celestial causes form the core of some thirty-three of these statements, grouped together to substantiate the Inquisition's judgment that Cardano assigned no limits to astrology or to the power of celestial influence. Overall, the list moves from general statements, certainly heterodox, to the sharp and dramatically heretical. The eighth statement reads: "Astrology is to be exalted above all other things." ${ }^{38}$ The following statements then establish astrology to be the highest discipline and astrologers the wisest of people, capable of predicting the fortune of a year and the happenings of a human life from the time of birth. The list builds to two dramatic corollaries: "Human conduct is not the result of choice (prohairesis)" and "We can thus conjecture from the stars the salvation and damnation of each person." ${ }^{49}$ Having nullified free will, the list moves on to what we might call the geopolitical implications of astrological determinism. The fortunes of religions are governed by natural causes, rendering them equivalent and emptying their histories of divine approval or wrath, as we see clearly in the corollary to statement 16: "Therefore, divine providence is to be erased. Therefore, the Jews do not suffer so many disasters as punishment for their sin, but naturally." ${ }^{50}$ The next group of statements all assert that religions themselves, their doctrines and fates, are determined by the stars. Cardano's geniture of Christ, according to the Inquisition reading, means that Christ's death and passion "did not happen of free will but necessity. Therefore, it is false that Christ wanted to make an offering of himself." ${ }^{51}$ Next the list turns to recent history, accusing Cardano of reducing the lives and teachings of Luther and Erasmus to natural causes and the pyric destiny of Savonarola to the same. If men like Luther and Erasmus only did what nature insisted, "then they were wrongly accused by the Church." ${ }^{2}$ The list then moves on to celestial influence, arriving at conclusions reached by earlier reports. Cardano, says the censor, has celestial influence ruling over mortals, explains martyrdom by natural causes that have nothing to do with the martyr's free will, and accuses "covetous priests" of inventing forms of worship.

The censorial list does not provide a nuanced portrait of Cardano's thought. Rather, it is a mixture of paraphrase and extrapolation from things he actually wrote to their most damning implications. No information is ever provided as to where statements were drawn from. In this, the list differs significantly from the censurae themselves, which copy suspect passages word for word and carefully note their provenance (work, book, chapter, and frequently page). While those reports cherry-pick statements, they do not fabricate new ones, as the list does. How did Cardano respond? In the brief preamble to his point-by-point response, he emphasizes that the Holy Office had provided no indication of where statements had been culled. This absence, he says, made it more difficult for him either to absolve himself or to offer corrections. So, where he is accused of putting astrology over all other things, he denies any memory of saying so. And if it turns out that he did say such a thing, he was speaking conventionally rather than making a declaration about nature. His response here could be construed as accurate, since he had made the statement in his

\footnotetext{
${ }^{48}$ Baldini and Spruit, eds., Catholic Church and Modern Science, pp. 1304, 1307 (judgments from thematic report), and 1331 (eighth heterodox proposition).

${ }^{49}$ Corollary of statement 14: "Mores humani non sunt ex prohaeresi." Corollary of statement 15: "Ergo ex astris coniecturare possumus salutem, et damnationem cuisque." Ibid., p. 1331.

${ }^{50}$ Corollary of statement 16: "Ergo divina providentia tollenda est: Ergo Iudei non patiantur tot incommoda in poenam commissi sceleris sed naturaliter." Ibid.

${ }^{51}$ Ibid., pp. 1331-1332. "The usual implications of the idea that stellar influences acted on Christ were that the passion and crucifixion were not undertaken voluntarily": North, "Astrology and the Fortunes of Churches" (cit. n. 47), p. 201.

52 Statement 22: "Ergo perperam culpantur ab Ecclesia." Baldini and Spruit, eds., Catholic Church and Modern Science, p. 1332.
} 
Encomium astrologiae (1543), where the genre practically demanded such immoderate rhetoric, as witnessed in countless sixteenth-century celebrations of medicine, geometry, astronomy, and assorted disciplines. ${ }^{53}$ Where he is accused of writing that astrology is not doubted, he claims the opposite to be true. The actual substance, means of movement, and speed of celestial bodies are unknown, as he declares in a surprising and probably less than sincere show of astronomical skepticism. Consequently, "we scarcely know a shadow of the future." ${ }^{54}$ Where he is accused of reducing the Christian religion to natural causes, he insists that he was speaking about what we might call the secular side of religion - religions as groups of people living in different places under different institutions, especially militaries. These worldly factors are in Cardano's mind subject to astrological influence, but ultimately they follow the historical plan of Providence. What about his claim of celestial influence ruling over mortals? "That proposition is against those philosophers who try to reduce everything to primary qualities. ${ }^{" 55}$ In other words, the elements are not enough to account for the things we see around us; the formal power of celestial influence is needed. This view was probably common enough. Jean Fernel, possibly the most influential medical theorist of the later sixteenth century (and an acquaintance of Cardano), had dedicated Book 1 of his De abditis rerum causis (1548) to this very point. ${ }^{56}$ And what about those blessed martyrs, apparently driven by the Moon to give up their security for some mere religious idea? Here Cardano claims that he meant only to say that certain aspects of heretical behavior-the capacity to abandon comforts and tolerate suffering-could be reduced to a natural cause. ${ }^{57}$ We have seen, however, that his writings implied much more than this.

The Congregation of the Index would for decades envisage an authoritative expurgation of popular and useful works, yet the project would never come to fruition. After delays, false starts, and institutional disagreements, a sort of semiofficial expurgatory index emerged in 1607. ${ }^{58}$ This index, compiled by the Master of the Sacred Palace Giovanni Maria Guanzelli, covered only fifty works, two of them from the pen of Cardano, the De subtilitate and the De rerum varietate. Book 2 , chapter 13 , of the De rerum varietate was severely corrected. While Guanzelli faithfully respected the consensus of earlier censors, his index made no attempt to represent anything approaching the number and breadth of accusations featured in the list of heterodox statements. He let stand, for example, Cardano's assertion that all mortals were ruled by celestial influence. Instead, he removed passages linking this influence with the behavior of heretics and martyrs; he even went so far as to censor the passage, translated above, insisting on the heavens, rather than God himself, as the proximate cause of sublunar generation. ${ }^{59}$ In any case, Guanzelli's index would prove problematic. It was immediately found inadequate by the Congregation, then revised but never reprinted. Recent work by Hannah Marcus establishes that the 1607 index was nevertheless widely used as a reference in granting licenses to read prohibited books. ${ }^{60}$

\footnotetext{
53 Girolamo Cardano, Encomium astrologiae, in Opera omnia, Vol. 5, p. 727.

${ }^{54}$ Reply to proposition 9. Baldini and Spruit, eds., Catholic Church and Modern Science, p. 1339.

${ }^{55}$ Reply to proposition 27. Ibid., p. 1341.

${ }^{56}$ Jean Fernel, On the Hidden Causes of Things: Forms, Souls, and Occult Diseases in Renaissance Medicine, trans. John M. Forrester (Leiden: Brill, 2005), pp. 121-395.

${ }^{57}$ Reply to propositions 30 and 31. Baldini and Spruit, eds., Catholic Church and Modern Science, p. 1341.

58 Giovanni Maria Guanzelli da Brisighella, Indicis librorum expurgandorum in studiosorum gratiam confecti tomus primus (Rome, 1607); regarding expurgation of the De rerum varietate see pp. 580-598.

${ }^{59}$ The censored passage begins "I marvel at all these people ...": Cardano, De rerum varietate (cit. n. 27), pp. 83-84. Guanzelli also purges a long passage on astrological fortune and propitious or unpropitious years. This passage had been flagged by the first censor in 1570 as advocating judicial astrology. Baldini and Spruit, eds., Catholic Church and Modern Science, p. 1049.

${ }^{60}$ On the Congregation's fruitless efforts to create an authoritative expurgatory index see Gigliola Fragnito, "The Central and Peripheral Organization of Censorship," in Church, Censorship, and Culture in Early Modern Italy, ed. Fragnito (cit. n. 4), pp. 13-49. For information related to Cardano, medical censorship, and the 1607 index see Hannah Marcus, "The Mind of
} 


\section{READING CARDANO AFTER THE INQUISITION}

The Inquisition's view of Cardano was not completely off the mark. He did naturalize heresy, at least to some extent, and he did mount attacks on the Inquisition's character and legitimacy. But it is also tempting to dismiss their reading. The Inquisition censors operated via a hermeneutics of presumed guilt. Beginning with an initial volley of accusations, they did not merely collect heterodox statements but classified and networked them in an effort to reveal fundamental heresies undergirding his thought. It is clear that they generally overlooked Cardano's efforts to qualify his astrological thinking, as when, in his De supplemento almanach (1538), he specified that "the Christian and Jewish religions are from God. However, the fortune of [their] militaries is governed by the celestial bodies." ${ }^{61}$ In fact, not only was the attempt at qualification dismissed; the notion that the military fate of Christianity could depend on the stars was singled out in the harshest possible language by the author of the thematic censura, who could not accept so unilateral a separation between temporal power and divine approbation. ${ }^{62}$ Cardano's astrological ambition and optimism elsewhere led him to be careless about distinctions between the natural and the divine. For example, in the genitures appended to the Supplementum, he wrote, "The fiery trigon truly nurtures the Christian religion, the watery that of Muhammad."63 In Savonarola's geniture, Cardano noted the importance of the star Spica virginis, reminding his readers of its presence in Christ's geniture: "It is frequently said that this star rules over (praesidere) our religion as a natural cause."64

With the above in mind, I would like to isolate one especially prominent point that the Inquisition either overlooked or did not find convincing: Cardano neither placed astrology above theology nor yoked God's liberty to the stars. Instead, he held astrology to constitute natural theology. ${ }^{65}$ When writing his infamous geniture of Christ, he declared his intention to prove that Ptolemaic astrology corroborated the exceptional status of Christ. Here, "natural reasons" (naturalibus rationibus) alone confirmed Christ's singularity. In demonstrating the harmony between Ptolemy and Christianity, he was also promoting a Ptolemy of his own devising; hence the fact that Christ's geniture appears in his commentary on the Tetrabiblos. Cardano had astrology doing more than furnishing signs of Christ's singularity. The celestial order was the instrumental cause of Christ's physical excellence. God had established the conditions for the heavens such that Christ's human body would receive an optimal temperament, corporeal beauty, and perpetual health. Since Christ was as naturally good as possible, this meant that "Christianity

the Censor: Girolamo Rossi, a Physician and Censor for the Congregation of the Index,” Early Sci. Med., 2018, 23:14-33. I would also draw the reader's attention to Marcus's fascinating view of expurgation as "the dark side of commonplacing": ibid., pp. 32-33. See also Marcus's Forbidden Knowledge: Medicine, Science, and Censorship in Early Modern Italy (Chicago: Univ. Chicago Press, forthcoming in 2020).

61 "Leges Christianae \& Iudaicae à Deo sunt, fortuna tamen militantium à superioribus gubernatur." Girolamo Cardano, De supplemento almanach, Ch. 22, in Opera omnia, Vol. 5, p. 590.

62 "In eodem cap. turpissima scribit non solum haeresi infestissima, sed etiam sevissima infidelitate referta, ita ut talia audire abhorreat auditus." Baldini and Spruit, eds., Catholic Church and Modern Science, p. 1303.

63 "Porro Christianam legem fovet igneus trigonus, Mahumeti aqueus." Girolamo Cardano, De exemplis centum geniturarum, in Opera omnia, Vol. 5, p. 463.

64 "Saepius autem dictum est, hanc stellam nostrae religioni praesidere, ut causam naturalem." Ibid., p. 490. Overall, the genitures were a major source of concern for the censors, who claimed that Cardano had reduced the lives of holy and heretical figures to a natural cause. For Cardano's genitures see Germana Ernst, “'Veritatis Amor Dulcissimus': Aspects of Cardano's Astrology," in Secrets of Nature: Astrology and Alchemy in Early Modern Europe, ed. William R. Newman and Anthony Grafton (Cambridge, Mass.: MIT Press, 2001), pp. 39-68.

${ }^{65}$ Pierre d'Ailly, whose views on the correspondence of theology and astrology resemble Cardano's, described his astrology as "natural theology." See Smoller, History, Prophecy, and the Stars (cit. n. 47), p. 122. 
is naturally a religion of piety, faith, simplicity, charity, and optimally established." ${ }^{66}$ The heavens, then, were a machine in the execution of fate and Providence, and they had been tuned to favor the Christian religion. Cardano's view was of course predicated on the dual nature of Christ, whose divinity was neither caused by nor subject to the heavens: "However, you should not believe that I am saying that the divinity in Christ, his miracles, the holiness of [his] life, or the promulgation of [his] law depend on the celestial bodies." ${ }^{67}$ Thus the divine transcends and governs nature. In other places we find Cardano espousing the kind of natural theology common in the sixteenth and seventeenth centuries. An omniscient creator, he writes in the De subtilitate, is needed to account for the perfect order of the universe, and the chain of natural causes must extend upward to nothing else but this creator. ${ }^{68}$ The natural and the divine, the philosophical and the theological, do not contradict one another, although Cardano condemned theologians who played irresponsibly with natural theology and spread pernicious fables of demons and witches. In his efforts to understand how they relate, Cardano could be said to follow the impulse of Catholic orthodoxy. A double truth, one for philosophy and another for theology, had for all intents and purposes been banned by the Church in 1513 through the papal bull Apostolici regiminis. Cardano offered a natural philosophy that he took to align with the basic doctrines of the Church and to overcome the threat posed by Pietro Pomponazzi to such a unity. ${ }^{69}$

The Inquisition censors thought differently. They understood him to subjugate religion to astrology. To bolster their case, they sought and found some of Cardano's most enthusiastic affirmations of astrology's status and efficacy. Modern readers, however, have noticed the split in Cardano's epistemological optimism. Anthony Grafton has pointed to a disjoint in Cardano's beliefs about divination, which can waver between confidence and skepticism; sometimes Cardano's world is that of fate and order, sometimes it is a place of haphazard. Cardano's divinatory abilities, as he himself describes them in the De vita, can sound like a combination of luck and inexplicable intuition; at other times he revels in the astonishing accuracy of his results. ${ }^{70} \mathrm{Eu}-$ genio Di Rienzo has described the deep uncertainty that Cardano expresses over the human capacity to understand fate and divine judgment, an uncertainty radical enough to imbue him at times with a Lutheran sensibility. ${ }^{71}$ Likewise, Alfonso Ingegno has argued that Cardano's major inheritance from Pomponazzi was an awareness of humanity's epistemological limits. ${ }^{72}$ To these observations we might add the following: the spiritual state of man - fallen and benightedremains at the core of Cardano's philosophy. This ostensible disjoint between epistemological

\footnotetext{
66 “. . . et naturaliter legem nostram esse legem pietatis, iustitiae, fidei, simplicitatis, charitatis, optimeque institutam.” Cardano, Commentariorum in Ptolemaeum (cit. n. 8), in Opera omnia, Vol. 5, p. 221.

67 "Nec tamen me velle credas dicere, quod vel divinitas in Christo, vel miracula eius, vel vitae sanctitas, vel legis promulgatio ab astris pendeant." Ibid.

${ }^{68}$ Cardano also lists a number of phenomena that reveal the presence of a creator: the possibility of divination, the origin of the human mind (which implies a more intelligent craftsman), basic human knowledge of good and evil (what writers of the period sometimes referred to as "natural light"), and political order. See Cardano, "De Subtilitate" of Girolamo Cardano (cit. n. 27), Vol. 2, pp. 998-999.

${ }^{69}$ Regarding Cardano's condemnation of irresponsible theologians see Ernst, "Cardan et les sorcières" (cit. n. 36), p. 6. On the major influence exerted by Pomponazzi on Cardano see Alfonso Ingegno, Saggio sulla filosofia di Cardano (Florence: Nuova Italia, 1980), pp. 1-78.

${ }^{70}$ See, e.g., Cardano's interpretation of a criminal's geniture shown to him by Georg Joachim Rheticus: Ernst, “'Veritatis Amor Dulcissimus'” (cit. n. 64), p. 57. For Grafton's view of Cardano's beliefs about divination see Anthony Grafton, Cardano's Cosmos: The Worlds and Works of a Renaissance Astrologer (Cambridge, Mass.: Harvard Univ. Press, 1999), pp. 174-177.

${ }^{71}$ Eugenio Di Rienzo, "La religione di Cardano: Libertinismo e eresia nell'Italia della controriforma," in Girolamo Cardano, ed. Kessler (cit. n. 2), pp. 49-76, esp. pp. 68-76. Valente writes of "the uneasy balance between determinism and free will that seems to lean him towards solafideism": Valente, "Facing the Roman Inquisition" (cit. n. 9), p. 537.

${ }^{72}$ Ingegno, Saggio sulla filosofia di Cardano (cit. n. 69), pp. 30-32.
} 
confidence and gloom is due to emphasis rather than essential fracture. Works like the De consolatione or the De vita meditate on the unexpected in human life, fortunate or otherwise. In these texts, any clear and definite reading of fate and Providence remains profoundly beyond the human ken. Moreover, whether we are searching for the ultimate sense of history or for certain knowledge about the future, our myopia is essential to our spiritual trial. The conclusion of the De consolatione finds Cardano describing the world as a theater constructed by God to observe us as we confront temptation - temptation from without via the Devil and from within via our senses. The text connects the theater with the invisibility of the divine observer: the theater is such that God can watch us secretly, and this is the secrecy of fate, of the script that has been written for us and of the judgment to be executed in the play's finale. At death, writes Cardano, we are removed from the theater in one of two ways: the deserving are lifted out and counted among the princes of God's kingdom; the others exit in chains. ${ }^{73}$

The astrologer, as Cardano sees him, is far more limited than the theoretical possibilities of his art, which nevertheless remains the most certain form of divination because it studies the noblest of natural causes, rather than merely signs. Astrology is, he specifies, not the science of fate tout court but, rather, the part of fate manifest in the order of the stars, as mentioned earlier. Hence there are matters of fate bound to escape the astrologer's most assiduous calculations, not to mention the difficulties inherent in going from astral position and quality to actual effects in an unwieldy and unpredictable sublunar matter. ${ }^{74}$ While some of Cardano's darkest passages describe the crushing unknown of our world, an ignorance both natural and spiritual, this pessimism does not elsewhere reduce his optimism as to the fundamental order and knowability of nature, and it is precisely this optimism that suffuses works like the De subtilitate and the De rerum varietate. In the dedicatory epistle to the latter work, Cardano writes that knowledge is what God holds most dear, and he means a kind of natural knowledge, an understanding of the world's constitution, including the human constitution. ${ }^{75}$ In other words, Cardano resembles many a good humanist for whom the goal of natural philosophy is self-knowledge, a knowledge of "our ends, and substance and origin." Any semblance of a decent and stable life depends on such knowledge, which remains pristine in a world full of sordid shocks and rare flights of grace. ${ }^{76}$ And, of course, a side benefit of learning philosophy is that it serves as a safeguard against harmful acts of religious sectarianism.

\section{CONCLUSION}

In 1688 Jacques-Bénigne Bossuet, Bishop of Meaux, published a long history of the Protestant churches, the Histoire des variations des Églises protestantes. This anti-Protestant work is, as its title says, a history of variation. "Variation," "subtilité," "équivoque," and "artifice" are the characteristics of heresy. ${ }^{77}$ In other words, then, Bossuet holds the true Catholic faith to be simple,

\footnotetext{
${ }^{73}$ Girolamo Cardano, De consolatione, in Cardano, Opera omnia, Vol. 1, p. 636.

${ }^{74}$ Cardano, Commentariorum in Ptolemaeum (cit. n. 8), in Opera omnia, Vol. 5, p. 94. See Guido Giglioni, "Man's Mortality, Conjectural Knowledge, and the Redefinition of the Divinatory Practice in Cardano's Philosophy," in Cardano e la tradizione dei saperi, ed. Baldi and Canziani (cit. n. 8), pp. 43-65, esp. p. 51.

75 "Ergo Deo sapiens charissimus est, idemque beatissimus esse debet." Cardano, De rerum varietate (cit. n. 27), fol. 3v (of introduction).

${ }^{76}$ Ibid., fol. 4r. Cardano more or less identifies this knowledge with the substance of the mind surviving death. For Cardano on the mind see Guido Giglioni, "Mens in Girolamo Cardano," in Per una storia del concetto di mente, ed. Eugenio Canone, 2 vols. (Florence: Olschki, 2005-2007), Vol. 2, pp. 83-122; and José Manuel García Valverde, "Averroistic Themes in Girolamo Cardano's De Immortalitate Animorum," in Renaissance Averroism and Its Aftermath: Arabic Philosophy in Early Modern Europe, ed. Anna Akasoy and Giglioni (Dordrecht: Springer, 2013), pp. 145-171.

77 Jacques-Bénigne Bossuet, Histoire des variations des Églises protestantes, 2 vols. (Paris, 1688), pp. iii-iv.
} 
clear, and immutable; heresy is multiplicity and invention. Once the Protestants deviated from the Church, they opened themselves up to endless fractures. Bossuet even gives a profile of the heresiarch, exemplified by Luther:

St. Gregory of Nazianzus does not represent the Heresiarchs as men without religion but as men who deeply misunderstand religion. They are, he says, great spirits, because weak souls are equally useless for good or for evil. But these great spirits, he continues, are at the same time ardent and impetuous spirits, who take up religion with an excessive ardor, which is to say, they have a false zealousness, and, mixing with religion a vainglorious angst, an unbreakable audacity, and their own spirit, they push everything to the extreme. ${ }^{78}$

Over a century earlier, Cardano had made subtlety, variety, and artifice his intellectual interests. He was their self-proclaimed master, precisely because, as a philosopher, he could trace them back to first causes. And his project even led him to explain religious variety, or the passions behind religious variety, through natural philosophy - that is, through the interaction between external, celestial factors and the human constitution. The difference between Cardano and a writer like Bossuet is that, for the former, questions of doctrine are ignored. Cardano does not believe he is doing theology but, rather, philosophy; from his point of view, extreme religious behavior - at the root of schisms and sects - is a natural condition demanding a philosophical or medical response. From the earliest document in his Inquisition affair, we see the Inquisition seizing on this idea, precisely because it sapped heresy of its force.

In this essay I have kept my focus more or less limited to the question of celestial influence and the place of astrology in Cardano's trial. I have made this methodological choice in order to trace a path for myself through the bristling corridors of Inquisition censurae and through Cardano's labyrinthine output. However, the study has revealed several important points that bear repeating. To begin with, the censors demonstrate a remarkably uniform vision of Cardano's astrological and natural philosophical trespasses. From the initial accusations listed in the Inquisitor of Como's letter, they build a consistent body of accusations networked to maximize the total weight of his guilt. The Inquisition strikes where it sees theological differences, but the trigger in this case was a direct threat against their legitimacy. How do we read Cardano after reading the Inquisition on Cardano? This will depend on how we have read Cardano before and where on the historiographical shelf we place the Inquisition. In this brief study, I have emphasized above all a moderate and humanist Cardano-a Cardano who, for all his self-promotion, was nonetheless aware of boundaries, whether disciplinary or confessional. Cardano's natural philosophy was an endeavor that he saw as useful in and of itself and as necessary for humanity in its power to lead practitioners toward self-knowledge. But he also viewed it, and particularly astrology, as a well-founded inquiry into the natural manifestations of divine Providence. Despite his enthusiasm, he clearly asserted in works read by his censors the superiority of revelation and theology, even as he believed that the natural and divine are unified at a level beyond our intellectual sight. In this, he attempted to create a system of thought incarnating the doctrine of one

\footnotetext{
78 "Saint Gregoire de Nazianze ne nous représente pas les Hérésiarques comme des hommes sans religion, mais comme des hommes qui prennent la Religion de travers. Ce sont, dit-il, de grands esprits : car les ames foibles sont également inutiles pour le bien \& pour le mal. Mais ces grands esprits, poursuit-il, sont en même temps des esprits ardens ङ impétueux, qui prennent la religion avec une ardeur démesurée, c'est-à-dire, qui ont un faux zele, \& qui, mêlant à la religion un chagrin superbe, une hardiesse indomptée, \& leur propre esprit, poussent tout à l'extrémité." Ibid., pp. 201-202.
} 
truth, and the result was a philosophy that functioned as ecumenical natural theology. But in the eyes of the Roman Inquisition, he succeeded only in lowering theology to the level of natural causes. Cardano's trial shows us, in conclusion, that the papal institutions of the late sixteenth century would not accept a view of nature threatening to undercut the justifications of their unique temporal power. 